\title{
Islamic Education in the Era of Technological Wave: A Case in Indonesia Today
}

\author{
Arif Rahman' \\ ${ }^{1}$ Universitas Ahmad Dahlan, Indonesia \\ Correspondence: arif.rahman9012@yahoo.com
}

\begin{abstract}
ABSRACT
The long journey of Islamic educational reform has come a new phase, in which Islamic education is no longer bound by the dichotomy paradigm or the Islamization of Science. But faced with a huge wave of technology that has touched all aspects of human life. Indonesia has turned into a market for technology companies of the world, but Islamic education has not been seen by intelligently utilizing current technological developments, as an integrated part in solving the problems that have not been able to be resolved in Islamic education itself. The dynamics of the encounter of technology to Islamic educational dimension in the case in Indonesia shows that the need for serious efforts to capitalize on opportunities both as a form of effective collaboration.
\end{abstract}

Keywords: Islamic Education; technology 


\section{INTRODUCTION}

Islamic reform movement has had a significant impact in the Islamic education itself. Islamic education was renewed in phase long enough. Departing from critics model of learning, teaching, the material that demands a contextual way of thinking has been carried out by Islamic reformers of his time. Muhammad Abduhfrom Egypt and Sayyid Ahmad Khan from India has given an example how they work to make changes in his country, despite resistance to all kinds of such reforms have come across various obstacles.

Fazlur Rahman even called Islamic Education has experienced stagnation that causes Muslims need to consider new ways of completing setback refreshing his people through education. Even the sweat and blood of contestation due to sectarian group (mazhab) in Islam which is so exhausting, Muslims have forgotten that the Europeans have made significant progress. Moreover, technology has become a powerful weapon for the Europe, especially for developing countries in mastering science. Indonesia has entered a phase where technology has touched every narrow hallway and entered in all the expanse of the city. The need for information so high put line technology has been popular in the hands of public, not least young children Indonesia. Social media, android, ios, google and a row of foreign development hardly their ears. So it can be seen that Indonesia has become a large market for all the tech giant. Including in education, took part in the technologies work together to sustain the knowledge and facilitate the workings of the human digging meaningful findings.

Amid the bustle of it all, Islamic education should certainly be a part that can not be detached from the phenomenon. Efforts to bring together technology and Islam is not a new issue, it is questionable how far their development until today ?but the answer to the use of technology can be said so far has not touched into substantive, but only just reached the level of recognition, consumptive, and called Azra that sometimes learning technology adds to the impression of complexity in technical matters. So that in turn lead to the rigidity of the process of creative learning and innovative. Though Amin Abdullah mention the "creative imagination" Should be a part of how to unite and coordinate ideas, even the two concepts are different framework, thus arrayed into fresh configurations. 
Defining Islamic education in Indonesia: Trend and transformation

Education and the pursuit of knowledge are central to Islam. The aim of education in Islam is to "produce good Muslims with an understanding of Islamic rules of behaviour and a strong knowledge of and commitment to the faith". Besides that, knowledge in Islam as a capital for its followers to understand the content of the source of Islam is the Qur'an and Sunnah.

Islamic education in Indonesia is said to be enough to survive in its implementation. But it is widely not quite able to compete with other public education institutions. Nevertheless, it should be given the appreciation of the persistence and innovation efforts undertaken in the dimension of education over the years. if compared to the other countries, Indonesian Islamic education has its own particularities that always give priority to the reconciliation efforts towards social dynamics, so that it seems to give enough credit positive points for his journey, including some reform efforts. A book edited by Charlene Tan "Islamic Education and indoctrination : The Case in Indonesia", illustrates that Islamic schools have a display with a friendly face. In the sense that the values of tolerance and harmony are quite encouraging in Indonesian society is built through the education process in schools.

Besides it is also known that development madrasah and Islamic schools lately shows positive side, in which the government gives serious attention by equalizing madrasah with other public schools. Islamic education here got fresh wind with their efforts to increase the madrasahand so are boarding schools. Even looks sort of the collaboration government with the community in the implementation of Islamic education in Indonesia. Madrasah and Islamic schools so far has been the featured educational institutions spread over several locations in Indonesia. Such as the emergence of "Integrated Islamic School" (Sekolah Islam Terpadu) for example, is part of the public expectations that their children receive religious instruction at the same general subjects . Similarly Madrasah plus is equipped with laboratories and scientific studies conducted outside of school activities.

There are some things in fact this time why the institutions of Islamic education in Indonesia is quite turned his face to look busy, it should be noted that; First, a clash of cultures in the global era into the main trigger such changes. Second, competition among nations requires the mastery of skill, knowledge and technology.Third, MEA (ASEAN Economic Community) factors no doubt have attracted the attention of 
Islamic education in Indonesia, both institutionally and in the educational process. These factors according to the author who became the bow of Islamic education in Indonesia today. This trend can be seen on the program of Islamic educational institutions, such as the independence of pesantren with computers to equip students capabilities, graphic design and other skills. Even in recent years the program "internet into the pesantren" (internet masuk pesantren) has been endemic and spreading in many schools.

At the college level are Also visible in the access to and use of online journals is increasing. Even trend -based online publication of the journal has been helping higher education institutions improve the Islamic universityrankings. Besides, the traffic exchange and access to knowledge Increasingly looks easy and efficient. Means of education is not limited to the boundaries of the classroom . The Internet has become a new window transmission of knowledge received by students. Youtube, Google and online video media is used as a tutorial, information, streaming class long distance, and become the warehouse of knowledge so promising . Coupled with the government program that welcomes competition Asean free market economy (ASEAN Economic Community), so that everywhere visible Islamic education are increasingly aware that it is no longer just sit and stare at the classical books affairs. Rather globalizing the Islamic tradition through technologies that make it easier for human life.

\section{Negotiating between tradition and globalization}

The new face of Islamic education, seen from trends and transformations in various lines of course does not just happen. The changes were made attraction between traditional and modernity. Due to the dominance of the West so that it appears such movements Islamization of Science, purification, and the like who tried to get back to the purity of the Islamic source, it is the Qur'an and Sunnah. Facing the onslaught from the West, Islamic educationists responded in two ways. One was Islamic reformism inspired by the thinking of an Al-Azhar professor, Muhammad Abduh (d. 1905) in Egypt, who advanced the idea of combining reason and faith. In concrete terms, this meant a combination of Western secular subjects and the teaching of Islam. This response was most typically represented in Indonesia by the Muhammadiyah movement established in Yogyakarta in 1912. By the end of the Dutch colonial rule in 1942, the Muhammadiyah spread its own networks of primary and secondary schools modelled after government schools, mostly in cities and towns. 
The second response to Western colonialism came from the traditionalist 'uiama and kyai of pondokpesantren. They formed Nandatul 'Ulama (NU) (Awakening of Islamic Scholars) in 1926 and reconfirmed their defence of the traditional Islamic scholarship centringaround the teaching of Islamic law. They refused any introduction of Western education or reformist rationalism. Basing themselves in the countryside of Java, NU built up and consolidated a large following among the rural population by the end of Dutch rule.

Experience in Indonesia has given a lesson which means, that the pattern of Islamic education in Indonesia look more mature, and have realized that the huge wave of modernity has had a significant impact. Especially in front of global competition. It should be recognized negotiation process has marked a change in the occurrence of an awareness of the need for mastery of various scientific capacity. On the practical level it will no doubt continue running, althought at the level of the paradigm is sometimes still struggling in the discussion which is quite tiring.

\section{From normative identity to ijtihady scientific: Collaboration \& integration of technology into Islamic education}

Awareness movement that brings together and collaborate on technologies into Islam is a smart way to deliver all religious moral message. Trend modern science now gives directions so that the effort and ijtihad in Islam made it easier to touch in real. Although it is not all that capable imposed in the process of rationalizing the religious normativity. Arkoun themselves are aware that Islamic thought "modern" has always been forbidden to ask a crucial investigations against al-Qur'an and Sunnah are preserved until today. If this tradition is still maintained, then the expectation of the Islamic education to greet modern science would be difficult to materialize. In fact, the current challenges and needs of the more urgent so that requires formulations that offer more fresh and not imposing on the patterns of old thought.

In practice well recognized by Azra, that is honest we have to admit, Islamic education today is often too late to formulate themselves seem to respond to changes and trends in the development of our society today and the future. Islamic education system most were still more likely to orientate themselves in the field of humanities and social sciences rather than some kind of exact sciences of physics, chemistry, biology and mathematics modern. Though fourth this science and the development of advanced technology is absolutely necessary. The exact sciences has not received the 
appreciation and proper place in the system of Islamic education. Associated with the Islamic education and the penetration of this technology wave, there are at least three main points in this discussion . First, Islam as a worldview is the basis of reasoning which has an area of study in itself. Second, Life Skills Needs of human (human needs). Third, the technology as part of the expansion era that was already in the public round.

In the first sphere, "Islamic worldview" somewhat already Mentioned in the previous sheet, the position of the Qur'an and Sunnah is a major source of Islamic teaching, all activities and decisions in Islam will not be Considered significant if it did not come from that source. chastity (taqdis) of the Qur'an and Sunnah by Muslim scholars regarded as a living text, so it Believed its presence is always contextual every era (Shalihun likull izaman wa al-makan). Looking at the second domain is a "human need" is continuity and endless. Changing times has caused all sorts bustle of human needs. From day to day it kept sticking. No denying that humans are looking for a wide range of solutions in the settlement needs met now, later and in the future. The need for human resources, expertise, education, skills and empowerment has become an instrument that fraction represents in this sphere .

Furthermore, related to "technology", became the third sphere is empirically try to give bids partial settlement of human anxiety. Her presence gives the effort to make the complex human life becomes simpler, parse complexity, facilitate access to knowledge, shorten the way to work, efficiency. therefore research and development is a key element in technological systems. The third realm above can not walk alone and feel isolated from each other. Even feel selfish at a time when the same time trying to answer the challenges of the times. But all three should be able to contact each others and give a new color. Consequences encounter three instruments provide some sort of perspective that is more "accommodating, rational, and relevant" for the advancement of Islamic education. Such as spawned a variety of software in Islamic learning, digitizing books turasts, and other conveniences as supporting to explore the Islamic sources.

Likewise also encounter technology and human needs, has given birth to "Y Generation". namely young people with some kind of thirst in using technology. like technology and information in the social media have given to the fact that young people represent growth of social media is a part of their lives. In this case, the positive side it can be seen that the significant role young people play the role of 
technology that has colored the bustle of human needs. Even in Indonesia, the dominance of young people about technology is very high, especially in the use of social media and information technology. From the third encounter did not rule out the next steps the process of integration that offers what is called the "Islamic Education Model of the $21^{\text {st }}$ Century". That is the result of the third synthesis process framework that is "actual, accommodating, and solving", where they are able to work with mutually utilize their respective advantages, to collaborate and integrate then offer a solution the problem in Islamic education.

The concept of Islamic education that can be simply illustrated in the figure below:

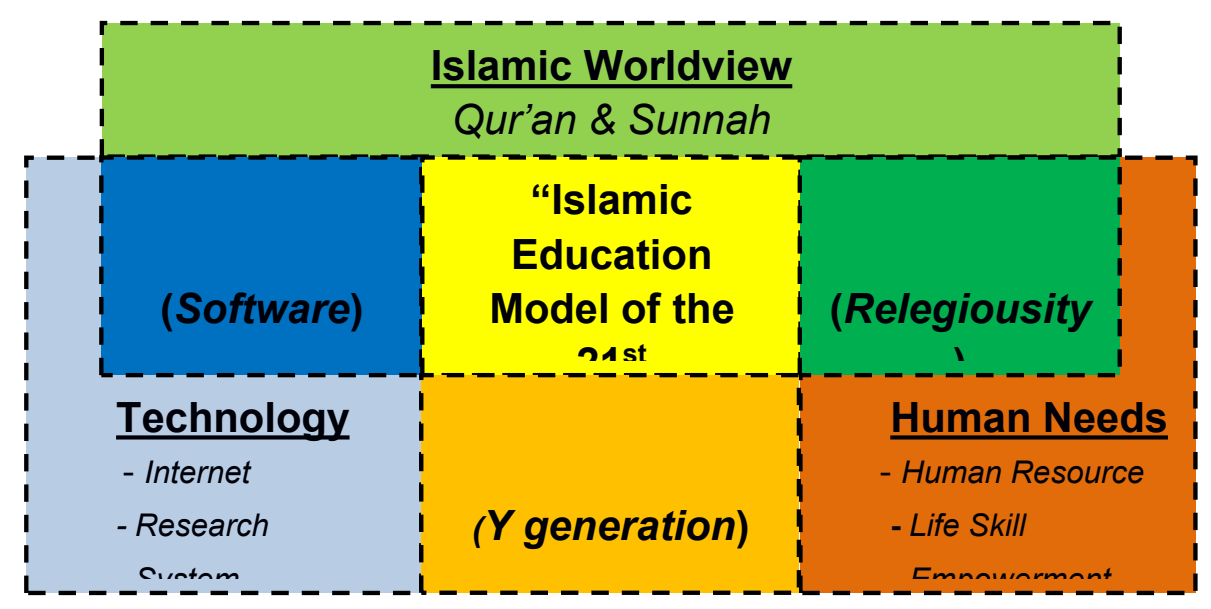

Picture: Islamic Education Model of the $21^{\text {st }}$ Century in Indonesia

\section{CONCLUSION}

Responding to the discussion of Islamic education in Indonesia, it is necessary to dissect the deepest. Today, the journey has entered a new phase of a wave of technology is so great. Basically Islamic education in Indonesia has an open nature on all forms of renewal, as well as the technology that comes later in the diverse face. Although it was the beginning of the encounter, there was a slight obstacle on the negotiation process at the level of principle. even so, openness and the spirit of Muslim reformers have given little encouragement of the change. Bids are accommodating educational model is necessary, that it is time for Islamic education utilize and synergize with all sorts of instruments of modern education. 


\section{REFERENCES}

Abdullah, Amin.(2009). Mempertautkan Ulum al-Din, al-Fikr al-Islamiy dan Dirasat Islamiyyah: Sumbangan Keilmuan Islam untuk Peradaban Global, in Marwan Saridjo (ed), Mereka Bicara Pendidikan Islam: Sebuah Bunga Rampai, (pp. 261-298). Jakarta: Radja Grafindo Persada

Arkoun, M. (2000). Membedah pemikiran Islam. Bandung: Pustaka

Azra, Azyumardi, (2012). Pendidikan Islam: Tradisi dan modernisasi di tengah tantangan milenium III. Jakarta: UIN Jakarta Press

Jackson, Elisabeth and Parker, Lyn. (2013). Enriched with knowledge': Modernisation, Islamisation and the future of Islamic education in Indonesia, Review of Indonesian and Malaysian Affairs, 42(1). Retrieved from https://search.informit.com.au/document Summary

Nakamura, Mitsuo\& Nishino,Setsuo. (1993). Islamic higher education in Indonesia, Higher Education Policy, 6(2), p. 51-54, doi: 10.1057/hep.1993.26

Noer, Deliar. (1996).Gerakan modern Islam di Indonesia 1900-1942. Jakarta: LP3ES,

Rahman, Fazlur. (1979).Islam ( $2^{\text {nd }} e d$.). Chicago: The Unversity of Chicago Press

Tan, Charlene, ed, (2011).Islamic Education and Indoctrination: case in Indonesia, London: Taylor \& Francis 